\title{
Microalgal Cultivation in Secondary Effluent: Recent Developments and Future Work
}

\author{
Junping Lv, Jia Feng, Qi Liu and Shulian Xie * \\ School of Life Science, Shanxi University, Taiyuan 030006, China; lvjunping024@sxu.edu.cn (J.L.); \\ fengj@sxu.edu.cn (J.F.); liuqi@sxu.edu.cn (Q.L.) \\ * Correspondence: xiesl@sxu.edu.cn; Tel./Fax: +86-351-701-8121 \\ Academic Editor: Yongsheng Chen \\ Received: 27 October 2016; Accepted: 28 December 2016; Published: 1 January 2017
}

\begin{abstract}
Eutrophication of water catchments and the greenhouse effect are major challenges in developing the global economy in the near future. Secondary effluents, containing high amounts of nitrogen and phosphorus, need further treatment before being discharged into receiving water bodies. At the same time, new environmentally friendly energy sources need to be developed. Integrating microalgal cultivation for the production of biodiesel feedstock with the treatment of secondary effluent is one way of addressing both issues. This article provides a comprehensive review of the latest progress in microalgal cultivation in secondary effluent to remove pollutants and accumulate lipids. Researchers have discovered that microalgae remove nitrogen and phosphorus effectively from secondary effluent, accumulating biomass and lipids in the process. Immobilization of appropriate microalgae, and establishing a consortium of microalgae and/or bacteria, were both found to be feasible ways to enhance pollutant removal and lipid production. Demonstrations of pilot-scale microalgal cultures in secondary effluent have also taken place. However there is still much work to be done in improving pollutants removal, biomass production, and lipid accumulation in secondary effluent. This includes screening microalgae, constructing the consortium, making use of flue gas and nitrogen, developing technologies related to microalgal harvesting, and using lipid-extracted algal residues (LEA).
\end{abstract}

Keywords: microalgae; the treatment of secondary effluent; pollutants removal; biomass production; lipid accumulation

\section{Introduction}

Wastewater treatment plants (WWTPs) have played a significant role in improving water environments and the efficient use of water resources. Secondary effluent from the anaerobic-anoxic-oxic $\left(\mathrm{A}^{2} / \mathrm{O}\right)$ process (the most commonly used wastewater treatment process in China), or processes derived from this, is considered to be low in organics, nitrogen, and phosphorus [1]. Generally the biological removal of nitrogen via an $\mathrm{A}^{2} / \mathrm{O}$ process is mainly dependent on nitrifying bacteria and denitrifying bacteria [2]. However some features of the process, such as slow growth rate, sensitivity to toxic shocks, $\mathrm{pH}$, and temperature change, are not conducive to the stable removal of nitrogen from wastewaters [3]. In China in particular, many WWTPs are facing pressures to improve effluent quality to meet the Chinese National First A-level Sewage Discharge Standard. This means that secondary effluent should not exceed the threshold of chemical oxygen demand (COD) $50 \mathrm{mg} / \mathrm{L}$, ammonium $5 \mathrm{mg} / \mathrm{L}$, total nitrogen (TN) $15 \mathrm{mg} / \mathrm{L}$, and total phosphorous (TP) $0.5 \mathrm{mg} / \mathrm{L}$. More importantly, some reports show that the threshold of nitrogen and phosphorus causing eutrophication in streams is $0.21-1.2$ and $0.01-0.1 \mathrm{mg} / \mathrm{L}$, respectively [4]. Tertiary treatment is, therefore, necessary to reduce the risk of eutrophication. Currently tertiary treatment technologies are developing rapidly, focusing on coagulation-sedimentation, adsorption, ion exchange, membrane 
technology, biological filtering, ozonation, and biological nutrient removal (BNR) process, etc. [5-10]. Specifically facilities have been upgrading their BNR process to meet the new standards for nitrogen and phosphorous discharges. At present, the most effective BNR processes are the Modified Bardenpho and the University of Cape Town (UCT) treatment process, which exhibit excellent nitrogen and phosphorus removal efficiency, as reviewed by Arita et al. [11]. Nevertheless these techniques have many disadvantages; for example, the instability of the treatment effect, high investment, high treatment cost, and difficulty in being popularized in large scale. Thus efficient, stable, low cost tertiary wastewater treatment systems are essential in reducing nitrogen and phosphorus concentrations in secondary effluent.

Fossil fuels are, currently, the main source of energy for human production activities. Excessive consumption of them accelerates the emission and accumulation of $\mathrm{CO}_{2}$, which results in the greenhouse effect and aggravates global climate change [12]. The combustion of fossil fuels also contributes to gaseous pollutants, such as $\mathrm{SO}_{2}, \mathrm{NO}_{\mathrm{x}}, \mathrm{CO}$, ozone, and volatile organic compounds and may have adverse effects on human health and the environment [13]. Biodiesel appears to be an attractive partial alternative to fossil fuels and a way to reduce carbon emissions and reduce the risk of environment pollution from nitrogen oxides and sulfur oxides. At present, biodiesel derived from oil crops, animal fats and waste oil plays an effective part in addressing the problems caused by the use of fossil fuels [14-17]. These bioresources do, however, have some disadvantages. For example, the production of oil crops requires huge tracts of arable land and fresh water [15], and the production of animal fats may not be sufficient to replace fossil fuels [17]. It is essential that we seek new bioresources for biodiesel production that need only limited or no additional arable land; that need minimal clean water or can use wastewater; and that, simultaneously, have high biomass and lipid productivity.

Microalgae consist of a wide range of autotrophic organisms. They have comparable photosynthetic efficiency to higher plants, rapid growth rate, and notable adaptability. Carbon, nitrogen, and phosphorus are essential elements for microalgal growth and can be effectively used via different metabolic pathways [18]. They therefore have potential advantages for the removal of pollutants from wastewater.

Some microalgae have been shown to be capable of doubling their biomass several times per day. For example, Ochromonas danica, grown in a system containing $40 \mathrm{~g} / \mathrm{L}$ waste cooking oil with acid values of $10.7 \mathrm{mg} \mathrm{KOH} / \mathrm{g}$, has a short doubling time of $12.1 \mathrm{~h}$ [19]. This short harvesting life will allow multiple and continuous harvesting of biomass throughout the year. Compared to many types of plants, microalgae are easy to cultivate and can produce a high yield of lipid for biodiesel production. As indicated by Nascimento et al. [20], microalgae with a lipid content varying from $13 \%$ to $49 \%$ have biodiesel productivity ranging from 3.4 to $23.0 \mathrm{~m}^{3} \cdot \mathrm{ha}^{-1} \cdot \mathrm{year}^{-1}$ in open raceway pond systems. By contrast, the biodiesel productivity of soybeans is only $0.446 \mathrm{~m}^{3} \cdot \mathrm{ha}^{-1} \cdot \mathrm{year}^{-1}$ [21]. Also, as reviewed by Bohutskyi and Bouwer [22], Harun et al. [23], and Sialve et al. [24], the microalgal biomass remaining after lipid extraction can be used to generate methane. Coupling biodiesel and methane production provides significant energy advantages, along with the sustainability and economic benefits from nutrient recycling. Microalgae can also fix $\mathrm{CO}_{2}$ from flue gas to enhance biomass and lipid production $[25,26]$. This mitigates the greenhouse effect. Microalgae can produce neutral lipids, which are particularly suitable as a potential alternative to fossil fuel. Accordingly, compared to existing bioresources, microalgae are regarded as an excellent alternative for biodiesel production.

\section{Advances in Microalgal Cultivation in Secondary Effluent}

\subsection{The Feasibility of Microalgal Cultivation in Secondary Effluent}

Cai et al. [18], Chen et al. [27], and Zeng et al. [28] reviewed many investigations into lipid accumulation and the biological removal of nitrogen and phosphorus via microalgae in diverse wastewaters. There are some challenges in cultivating microalgae in wastewater, including unbalanced $\mathrm{N} / \mathrm{P}$ ratio, the presence of bacterial contamination and competitors, low biomass density and 
lipid content, and incomplete removal of nutrients [29-31]. Nevertheless these studies effectively demonstrate that wastewaters can be an excellent medium for biomass production and lipid accumulation and that nitrogen and phosphorus are also removed from wastewaters.

The physical and chemical characteristics of secondary effluent are completely different from those of municipal wastewater, anaerobic digestion effluent, industrial wastewater, and agricultural wastewater. Nearly all pollutants with high biodegradability in wastewaters are degraded in WWTPs, and the biodegradability of the remaining organic compounds in secondary effluent is poor. It has been reported that the ratio of BDOC/DOC (BDOC: biodegradable dissolved organic carbon; DOC: dissolved organic carbon) in secondary effluent is around 0.25 [32]. The lack of a carbon source is, therefore, a serious challenge for microalgal cultivation with secondary effluent. Li et al. [33] isolated a freshwater microalga, Scenedesmus sp. (LX1), and cultivated it with secondary effluent to investigate its ability to remove pollutants and accumulate lipids. The results indicated that Scenedesmus sp. (LX1) was well adapted to secondary effluent. The microalgal biomass and lipid content was $0.11 \mathrm{~g} / \mathrm{L}$ and $31 \%-33 \%$, respectively, after 15 days batch cultivation. At the same time, concentrations of nitrogen and phosphorus in the secondary effluent were decreased by $98 \%$ and $98.5 \%$, respectively. Several other microalgae, such as Botryococcus braunii and Chlorella ellipsoidea (YJ1), have also been grown in secondary effluent for biomass production and pollutant removal, although the microalgal biomass was below $0.5 \mathrm{~g} / \mathrm{L}$ [34,35]. Importantly the lipid content of C. ellipsoidea (YJ1) was up to $43 \%$ [26]. In other studies, microalgal lipid accumulation has been strengthened by nutrient starvation [35]. Consequently, although biomass production may be low, high lipid content can be achieved with low nutrient concentrations in secondary effluent.

Some filamentous, mat-forming cyanobacteria affiliated to Phormidium have been isolated from Arctic, subarctic, and Antarctic environments to investigate their potential for tertiary wastewater treatment in cool climates. These cyanobacteria exhibited superior growth and high phosphate uptake rates under cold temperatures $\left(10\right.$ and $5{ }^{\circ} \mathrm{C}$, respectively) and formed aggregates that could readily be harvested by sedimentation [36,37]. These interesting studies provide avenues for further research and lay the foundations for microalgal cultivation and tertiary wastewater treatment in regions of high altitudes and latitudes with cold climates.

\subsection{Microalgal Lipid Production in Secondary Effluent}

Although low nutrient concentrations in secondary effluent are beneficial to microalgal lipid accumulation, microalgal biomass production is inhibited (as seen in the studies described in Section 2.1), and this shortcoming needs to be addressed. Some studies have found that relatively high biomass was obtained when microalgae were cultivated in secondary effluent. For example, biomass production of S. obliquus and B. braunii, cultivated in secondary effluent, was up to 1.684 and $1.88 \mathrm{~g} / \mathrm{L}$, respectively $[38,39]$. The possible reason for this was supplementation with $\mathrm{CO}_{2}$ as an inorganic carbon source, promoting microalgal growth. Park et al. [40] found that three strains, Chlamydomonas debaryana AMB1, C. sorokiniana RBD8 and Micractinium sp. RB1b, showed large increases in biomass productivity when cultivated mixotrophically in secondary municipal wastewater supplemented with glycerol. This indicates that the exogenous supplement of an organic carbon source helped to strengthen the biomass production of microalgae. The adaption to secondary effluent was species-dependent. Compared to the high biomass production of Muriellopsis sp. and S. subpicatus in secondary effluent, C. vulgaris, C. fusca, Chlorella sp., and Pseudokirchneriella subcapitata had low biomass production in the same conditions [41]. Similar results were also found in other investigations [39]. Selection of the most appropriate microalgae is clearly critical to producing high biomass in secondary effluent.

\subsection{Microalgal Immobilization}

Immobilization technology is a good choice for harvesting or separating microalgal biomass from reactors. However the main focus of microalgal immobilization for secondary effluent treatment has been to enhance removal of pollutants. At present, the most widely used material 
for microalgal immobilization is alginate. A major advantage of alginate beads containing immobilized microalgae is that immobilized microalgae do not suffer extreme physical and/or chemical changes in the process of immobilization. In addition, the excellent permeability, low or null toxicity, and high transparency of alginate matrix provide a suitable environment for immobilized microalgae. As reported, Chlorella sp. and Scenedesmus sp., immobilized by alginate matrix, showed high removal efficiency of nitrogen and phosphorus (more than 90\%), when some other factors (cell density and starvation) were simultaneously optimized [42-44]. Chitosan- and carrageenan- immobilized microalgae (Phormidium, S. bicellularis, S. quadricauda) were also efficient in removing nitrogen and phosphorus from secondary effluent [45-47]. Although the removal of pollutants is mainly dependent on microalgal assimilation, immobilized matrixes also promote the removal of pollutants. As discussed by Tam and Wong [48], the presence of calcium ions in alginate matrix, together with elevated wastewater $\mathrm{pH}$, favored the precipitation of phosphate as calcium phosphate. Similarly the calcium dissolved as a result of abrasion of the chitosan particles in wastewater seemed to be conducive in reducing orthophosphate levels in the effluent [46]. Of course, the possible linkages or ionic exchanges between the orthophosphate and chitosan amide groups may provide exchange or fixation sites for orthophosphate [46]. Covarrubias et al. [49] found that the populations of C. sorokiniana and Azospirillum brasilense in non-sterile secondary effluent were significantly lower than in sterile wastewater when they were cultivated as free suspensions, and the population of wastewater bacteria and natural microfauna increased. However immobilization of $C$. sorokiniana and A. brasilense in polymer Ca-alginate beads significantly enhanced their populations in non-sterile secondary effluent. Alginate beads clearly provided a beneficial physical barrier against native microorganisms in secondary effluent.

Attaching to surfaces or matrices in the natural environment is normal for many microorganisms [50], and microalgae can attach to different kinds of materials. C. vulgaris and Scenedesmus sp. have been found to attach to carriers made from bundles of polypropylene fibers, and the microalgal biofilm photobioreactor thus created significantly reduced more than $90 \%$ of ammonium and total phosphorus in secondary effluent $[51,52]$. Concrete slabs have also been used as carriers for microalgal growth when pollutants from secondary effluent were removed effectively [53]. A rotating algal biofilm reactor (RABR) for wastewater treatment with in situ biomass harvest has been reported in some studies [54,55]. The RABR consists of a cylinder provided with a growth surface partially submerged in wastewater. The cylinder is rotated to alternately expose the growth surface to the wastewater and to air. Of course, effective growth substrata are crucial to microalgal attachment and biofilm formation in RABR [54,55]. Additionally the Algal turf scrubber (ATS), using a natural mixed assemblage of attached periphyton, microalgae, and bacteria, has been developed [56,57]. The ATS is a long inclined flow-way that supports a biofilm of microalgae and bacteria. When wastewater washes over the flow-way in a series of pulses, pollutants are removed effectively. To date, ATSs have been used to provide tertiary treatment of municipal wastewaters and have performed very well $[58,59]$.

Although all the above examples demonstrate that immobilized microalgae were beneficial in improving pollutants removal, partial biological degradation of alginate beads was observed during tertiary wastewater treatment [60]. Immobilization also had some negative effects on microalgal growth rate and biomass productivity [61]. Other unfavorable factors, such as low light penetration and high cost, have limited the commercial application of microalgal immobilization in tertiary wastewater treatment [62].

\subsection{Construction of a Microalgal Consortium}

Microalgae are generally grown as monocultures for harvesting high-value products. However to take advantage of the synergetic growth of microalgae and bacteria, a consortium of the two has been developed to treat wastewater with high levels of organic pollutants [63-65]. The consortium is also robust in the face of environmental fluctuations, resists the invasion of other species, and enhances the stability of reaction systems [66]. De-Bashan et al. [67] found that a mixed culture of microalgae 
(C. vulgaris or C. sorokiniana) and a bacterium (A. brasilense strain $\mathrm{Cd}$ ) immobilized into small alginate beads improved the efficiency of nitrogen and phosphorus removal from secondary effluent, compared to microalgae alone. The mixed culture removed $100 \%$ ammonium, $15 \%$ nitrate, and $36 \%$ phosphorus, a result that was superior to microalgae alone (75\% ammonium, $6 \%$ nitrate, and $19 \%$ phosphorus). To identify the appropriate combination of microalgae to enhance biomass productivity in secondary effluent, Scenedesmus sp. (LX1), C. ellipsoidea, and Haematococcus pluvislis, were chosen for a study of the growth characteristic of different microalgal combinations in secondary effluent [68]. The intrinsic growth rate of the three microalgae in the mixed culture was higher than when they were grown as monocultures. Biomass productivity in the mixed cultures of Scenedesmus sp. (LX1) and H. pluvialis increased by $64 \%$ and $42 \%$, respectively, compared to monocultures of Scenedesmus sp. (LX1) and H. pluvialis. These cases suggest that the efficiency of pollutants removal and biomass productivity are strengthened by constructing the consortium.

\subsection{Pilot-Scale Culture of Microalgae in Secondary Effluent}

Pilot-scale culture of microalgae in secondary effluent has been developed gradually. Van Coillie et al. [69] tested the feasibility of a tertiary treatment using Scenedesmus sp. at pilot-scale level. An outdoor tank with a capacity of $15,000 \mathrm{~L}$ was used for batch culture. Results showed that nutrient removal was $95 \%$ for total inorganic nitrogen and $60 \%$ for $\mathrm{PO}_{4}{ }^{3-}$ and that the biomass productivity was $0.39 \mathrm{mg} \cdot \mathrm{L}^{-1} \cdot \mathrm{h}^{-1}$. McGinn et al. [70] operated a $300 \mathrm{~L}$ proprietary Brite-Box photobioreactor for microalgal cultivation in secondary effluent. They showed that biomass productivity averaged $130 \mathrm{mg} \cdot \mathrm{L}^{-1} \cdot$ day $^{-1}$, and nitrogen and phosphorus removal could be up to $90 \%$, when average hydraulic retention times ranged from 6.55 to 6.65 days and from 6.50 to 6.56 days, respectively. Arbib et al. [71] operated a $530 \mathrm{~L}$ high rate alga pond (HRAP) and a $380 \mathrm{~L}$ airlift tubular photobioreactor (TPBR) to remove nitrogen and phosphorous from WWTP effluent. Maximum areal productivity was 8.26 and $21.76 \mathrm{~g}$ suspension solid (SS) $\cdot \mathrm{m}^{-2}$. day ${ }^{-1}$ for HRAP and TPBR, respectively; total nitrogen removal averaged $89.68 \%$ and $65.12 \%$ for TPBR and HRAP, respectively; and, for total phosphorus removal, TPBR and HRAP averaged $86.71 \%$ and $58.78 \%$, respectively. There was no significant lipid content difference between the reactors, which was about $20.8 \%$. Based on these studies, it appears that tertiary wastewater treatment and biomass production by microalgal cultivation is feasible at a pilot-scale level, and this provides a basis for large-scale cultivation of microalgae in secondary effluent.

\section{Future Research into Microalgal Cultivation in Secondary Effluent}

The progress in research examined here clearly indicates that microalgae have some potential to biomass production, lipid accumulation and pollutant removal in secondary effluent. However considerable work remains to be done to enhance lipid productivity, wastewater treatment efficiency, and microalgal harvesting in the future.

\subsection{Screening Microalgae and Constructing the Microalgal Poly-Culture and Microalgal-Bacterial Co-Culture Consortium}

Many microalgae, such as Chlorella, Scenedesmus, and Botryococcus, have been screened for biomass production [72-74]. Nevertheless, compared to those microalgae growing well in municipal wastewater, the diversity of microalgae growing in secondary effluent is low. The main groups focused on Chlorella and Scenedesmus (Table 1). In addition, the removal efficiency of nitrogen and phosphorous and lipid productivity during long-term operation was not good (Table 2). It was found to be essential to screen more microalgae to determine their suitability for growth in secondary effluent and to evaluate their lipid accumulation and biomass production potential. Whether oil-rich microalgae growing well in municipal wastewater could adapt to the new environmental conditions of secondary effluent remains to be explored. 
Table 1. Biomass production, lipid productivity, and pollutant removal of microalgae in secondary effluent under batch culture.

\begin{tabular}{|c|c|c|c|c|c|c|c|c|c|c|c|c|c|c|c|}
\hline \multirow[b]{2}{*}{$\begin{array}{l}\text { Microalgae } \\
\text { Species }\end{array}$} & \multirow[b]{2}{*}{$\begin{array}{l}\text { Free Cell (F) or } \\
\text { Immobilization } \\
\text { (I) }\end{array}$} & \multirow[b]{2}{*}{$\begin{array}{l}\text { Preliminary } \\
\text { Treatment of } \\
\text { Wastewater }\end{array}$} & \multirow[b]{2}{*}{$\begin{array}{l}\text { The Volume of } \\
\text { the Cultivation } \\
\text { (L) }\end{array}$} & \multirow[b]{2}{*}{$\begin{array}{l}\text { Cultivation } \\
\text { Time (h) }\end{array}$} & \multirow[b]{2}{*}{$\mathrm{CO}_{2}(\%)$} & \multicolumn{4}{|c|}{ Biomass Energy } & \multicolumn{5}{|c|}{ Nutrients Removal Efficiency (\%) } & \multirow[b]{2}{*}{ References } \\
\hline & & & & & & $\begin{array}{c}\text { Biomass } \\
\text { Production } \\
\left(\mathrm{g} \cdot \mathrm{L}^{-1} \text { ) }\right.\end{array}$ & $\begin{array}{c}\text { Biomass } \\
\text { Productivity } \\
\left.\text { (mg } \mathrm{L}^{-1} \cdot \text { day }^{-1}\right)\end{array}$ & $\begin{array}{c}\text { Lipid } \\
\text { Productivity } \\
\left(\mathrm{mg}^{2} \cdot \mathrm{L}^{-1} \cdot \text { day }^{-1}\right)\end{array}$ & $\begin{array}{c}\text { Lipid } \\
\text { Content } \\
(\%)\end{array}$ & COD & $\mathrm{TN}$ & $\mathrm{NH}_{4}{ }^{+}$ & $\mathrm{NO}_{3}^{-}$ & TP & \\
\hline $\begin{array}{l}\text { a natural } \\
\text { algal bloom }\end{array}$ & $\mathrm{F}$ & no treatment & 2 & 240 & 5 & 1.884 & 200.4 & - & 26.82 & - & 79 & - & - & $>98$ & {$[38]$} \\
\hline $\begin{array}{c}\text { Botryococcus } \\
\text { braunii }\end{array}$ & $\mathrm{F}$ & $\begin{array}{l}\text { filtration }(0.2 \mu \mathrm{m}) \\
\text { and autoclaving }\end{array}$ & 3 & 240 & 1 & 0.35 & - & - & - & - & - & - & $>99$ & $>99$ & [34] \\
\hline $\begin{array}{l}\text { Botryococcus } \\
\text { braunii }\end{array}$ & $\mathrm{F}$ & filtration & 0.5 & 1000 & - & - & $288-345.6$ & - & 17.85 & - & - & - & - & - & [75] \\
\hline $\begin{array}{c}\text { Botryococcus } \\
\text { braunii }\end{array}$ & $\mathrm{F}$ & no treatment & 9 & 336 & 5 & 1.88 & - & - & 36.14 & - & - & - & 79.63 & 100 & [39] \\
\hline $\begin{array}{c}\text { Chlorella } \\
\text { ellipsoidea YJ1 }\end{array}$ & $\mathrm{F}$ & $\begin{array}{l}\text { filtration }(0.45 \mu \mathrm{m}) \\
\text { and autoclaving }\end{array}$ & 0.3 & 528 & - & 0.425 & - & 12.7 & 43 & - & $>99$ & - & - & $>90$ & [35] \\
\hline $\begin{array}{c}\text { Chlorella } \\
\text { kessleri }\end{array}$ & $\mathrm{F}$ & no treatment & 2 & 240 & 5 & 1.172 & 132.3 & - & 20.55 & - & $>90$ & - & - & $>98$ & [38] \\
\hline $\begin{array}{c}\text { Chlorella } \\
\text { sorokiniana }\end{array}$ & $\mathrm{F}$ & autoclaving & 1 & 96 & 12 & 0.25 & 62.5 & 8 & 32 & - & - & - & 100 & 0 & {$[76]$} \\
\hline $\begin{array}{c}\text { Chlorella } \\
\text { sorokiniana }\end{array}$ & $\mathrm{F}$ & no treatment & 0.45 & 240 & - & 0.1 & - & - & - & - & 80 & - & - & 40 & [77] \\
\hline $\begin{array}{l}\text { Chlorella sp. } \\
227\end{array}$ & $\mathrm{~F}$ & $\begin{array}{l}\text { filtration }(0.45 \mu \mathrm{m}) \\
\text { or UV-radiation }\end{array}$ & 0.5 & 216 & - & $0.41-0.67$ & - & $6.9-22.9$ & $15-31$ & $13.8-24.8$ & $75-92$ & - & - & $84-86$ & [78] \\
\hline $\begin{array}{l}\text { Chlorella } \\
\text { vulgaris }\end{array}$ & $\mathrm{F}$ & no treatment & 2 & 120 & - & $0.76-0.82$ & $73.88-79.82$ & - & - & - & - & - & - & 92 & [79] \\
\hline $\begin{array}{l}\text { Chlorella } \\
\text { vulgaris }\end{array}$ & $\mathrm{F}$ & filtration $(0.2 \mu \mathrm{m})$ & 0.2 & 168 & 15 & 0.29 & - & - & 30 & - & $>99$ & - & - & $>99$ & [80] \\
\hline $\begin{array}{l}\text { Chlorella } \\
\text { vulgaris }\end{array}$ & $\mathrm{F}$ & no treatment & 2 & 240 & 5 & 1.303 & 116 & - & 22.02 & - & $>90$ & - & - & $>98$ & [38] \\
\hline $\begin{array}{l}\text { Chlorella } \\
\text { vulgaris }\end{array}$ & $\mathrm{F}$ & filtration & 2 & 168 & air $^{\mathrm{a}}$ & 1.03 & 171.33 & 43.52 & 27.6 & - & - & - & 94 & - & {$[81]$} \\
\hline $\begin{array}{l}\text { Desmodesmus } \\
\text { communis }\end{array}$ & $\mathrm{F}$ & filtration & 1 & 360 & 2 & 0.79 & 23 & - & 9.3 & & & & 100 & & [82] \\
\hline $\begin{array}{c}\text { Neochloris } \\
\text { oleoabundans }\end{array}$ & $\mathrm{F}$ & $\begin{array}{l}\text { filtration }(1.2 \mu \mathrm{m}) \\
\text { and autoclaving }\end{array}$ & 0.4 & 240 & 5 & 2.1 & 233.3 & - & - & - & - & $>90$ & $78-99$ & 100 & [83] \\
\hline $\begin{array}{l}\text { Ourococcus } \\
\text { multisporus }\end{array}$ & $\mathrm{F}$ & filtration $(0.2 \mu \mathrm{m})$ & 0.2 & 168 & 15 & 0.31 & - & - & 31 & - & $>99$ & - & - & $>99$ & [80] \\
\hline $\begin{array}{c}\text { Scenedesmus } \\
\text { obliquus }\end{array}$ & $\mathrm{F}$ & $\begin{array}{c}\text { filtration and } \\
\text { autoclaving }\end{array}$ & 1 & 192 & - & - & - & - & 31.4 & - & - & $>90$ & - & $>90$ & [84] \\
\hline $\begin{array}{l}\text { Scenedesmus } \\
\text { obliquus }\end{array}$ & $\mathrm{F}$ & filtration $(0.2 \mu \mathrm{m})$ & 0.2 & 168 & 15 & 0.31 & - & - & 27 & - & $>99$ & - & - & $>99$ & [80] \\
\hline $\begin{array}{l}\text { Scenedesmus } \\
\text { obliquus }\end{array}$ & $\mathrm{F}$ & no treatment & 2 & 240 & 5 & 1.684 & 201.4 & - & 19.38 & - & $>90$ & - & - & $>98$ & {$[38]$} \\
\hline
\end{tabular}


Table 1. Cont.

\begin{tabular}{|c|c|c|c|c|c|c|c|c|c|c|c|c|c|c|c|}
\hline \multirow[b]{2}{*}{$\begin{array}{l}\text { Microalgae } \\
\text { Species }\end{array}$} & \multirow[b]{2}{*}{$\begin{array}{l}\text { Free Cell (F) or } \\
\text { Immobilization } \\
\text { (I) }\end{array}$} & \multirow[b]{2}{*}{$\begin{array}{l}\text { Preliminary } \\
\text { Treatment of } \\
\text { Wastewater }\end{array}$} & \multirow[b]{2}{*}{$\begin{array}{l}\text { The Volume of } \\
\text { the Cultivation } \\
\text { (L) }\end{array}$} & \multirow[b]{2}{*}{$\begin{array}{l}\text { Cultivation } \\
\text { Time (h) }\end{array}$} & \multirow[b]{2}{*}{$\mathrm{CO}_{2}(\%)$} & \multicolumn{4}{|c|}{ Biomass Energy } & \multicolumn{5}{|c|}{ Nutrients Removal Efficiency (\%) } & \multirow[b]{2}{*}{ References } \\
\hline & & & & & & $\begin{array}{l}\text { Biomass } \\
\text { Production } \\
\left(\mathrm{g} \cdot \mathrm{L}^{-1}\right)\end{array}$ & 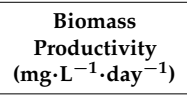 & 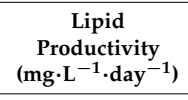 & $\begin{array}{c}\text { Lipid } \\
\text { Content } \\
(\%)\end{array}$ & COD & $\mathrm{TN}$ & $\mathrm{NH}_{4}^{+}$ & $\mathrm{NO}_{3}{ }^{-}$ & TP & \\
\hline $\begin{array}{l}\text { Scenedesmus } \\
\text { sp. AMDD }\end{array}$ & $\mathrm{F}$ & filtration $(0.2 \mu \mathrm{m})$ & 0.15 & 288 & $\begin{array}{c}\text { unknown } \\
\text { concentration }\end{array}$ & 0.13 & $127.22-132.73$ & - & $11.72-12.08$ & - & - & $>90$ & - & $>90$ & [40] \\
\hline $\begin{array}{l}\text { Scenedesmus } \\
\text { sp. LX1 }\end{array}$ & $\mathrm{F}$ & $\begin{array}{l}\text { filtration }(0.45 \mu \mathrm{m}) \\
\text { and autoclaving }\end{array}$ & 0.2 & 360 & - & 0.11 & - & 35 & $31-33$ & - & 98.5 & - & - & 98 & [33] \\
\hline $\begin{array}{l}\text { Scenedesmus } \\
\text { sp. LX1 }\end{array}$ & $\mathrm{F}$ & autoclaving & 0.2 & 336 & 5 & 0.77 & - & - & 35 & - & - & - & - & - & [85] \\
\hline Chlorella sp. & I & $\begin{array}{l}\text { filtration and } \\
\text { autoclaving }\end{array}$ & 0.35 & 8 & air & - & - & - & - & - & - & 100 & - & 100 & [44] \\
\hline $\begin{array}{l}\text { Phormidium } \\
\text { sp. }\end{array}$ & I & no treatment & 0.5 & 24 & - & - & - & - & - & - & - & $>90$ & $>90$ & $>90$ & [46] \\
\hline $\begin{array}{c}\text { Scenedesmus } \\
\text { bicellularis }\end{array}$ & I & unknown & unknown & 2 & - & $1.57-1.86$ & - & - & - & - & - & 100 & - & $88-100$ & [42] \\
\hline $\begin{array}{l}\text { Scenedesmus } \\
\text { bicellularis }\end{array}$ & I & autoclaving & 2.5 & 2 & $750-1500^{\mathrm{b}}$ & - & - & - & - & - & - & $42.1-100$ & - & $19.1-99.1$ & [86] \\
\hline $\begin{array}{l}\text { Seenedesmus } \\
\text { quadricauda }\end{array}$ & I & roughly screened & 1 & 3 & - & - & - & - & - & - & - & $85-100$ & - & - & [45] \\
\hline $\begin{array}{l}\text { Scenedesmus } \\
\text { sp. }\end{array}$ & I & $\begin{array}{l}\text { filtration and } \\
\text { autoclaving }\end{array}$ & 0.35 & 4 & air & - & - & - & - & - & - & 100 & - & 100 & [43] \\
\hline $\begin{array}{l}\text { Scenedesmus } \\
\text { sp. }\end{array}$ & I & no treatment & 96 & 72 & - & - & - & - & - & 0 & 47.86 & 96 & - & $>90$ & [52] \\
\hline
\end{tabular}

${ }^{\mathrm{a}}$ Except air, the system was supplied by $\mathrm{NaHCO}_{3} ;{ }^{\mathrm{b}} \mathrm{ppm}$.

Table 2. Biomass production, lipid productivity, and pollutant removal of microalgae in secondary effluent under continuous culture.

\begin{tabular}{|c|c|c|c|c|c|c|c|c|c|c|c|c|c|}
\hline \multirow[b]{2}{*}{ Microalgae Species } & \multirow[b]{2}{*}{$\begin{array}{l}\text { Free cell (F) or } \\
\text { Immobilization } \\
\text { (I) }\end{array}$} & \multirow[b]{2}{*}{$\begin{array}{l}\text { Cultivation } \\
\text { Time (d) }\end{array}$} & \multirow[b]{2}{*}{$\begin{array}{c}\text { Hydraulic } \\
\text { Retention } \\
\text { Time (d) }\end{array}$} & \multicolumn{4}{|c|}{ Biomass Energy } & \multicolumn{5}{|c|}{ Nutrients Removal Efficiency (\%) } & \multirow[b]{2}{*}{ References } \\
\hline & & & & $\begin{array}{l}\text { Biomass } \\
\text { Production } \\
\left(\mathrm{g} \cdot \mathrm{L}^{-1}\right)\end{array}$ & 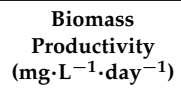 & 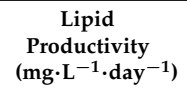 & $\begin{array}{l}\text { Lipid Content } \\
\quad(\%)\end{array}$ & COD & $\mathrm{TN}$ & $\mathrm{NH}_{4}{ }^{+}$ & $\mathrm{NO}_{3}{ }^{-}$ & TP & \\
\hline Chlorella vulgaris & F & 240 & $0.04-2$ & $0.69-1.289^{a}$ & $47.5-131.7$ & - & - & - & $54-95.3$ & & - & $84.4-94.9$ & [87] \\
\hline Scenedesmus sp. AMDD & $\mathrm{F}$ & 24 & 1.48 & $0.312-0.356$ & $234-267$ & $11.91-15.19$ & $5.14-5.70$ & - & - & 100 & - & 100 & [70] \\
\hline Scenedesmus obliquus & $\mathrm{F}$ & 112 & 5 & - & $21.76^{\mathrm{b}}$ & - & 20.8 & - & 89.68 & - & - & 86.71 & [71] \\
\hline Scenedesmus obliquus & $\mathrm{F}$ & 104 & 10 & - & $8.26^{\mathrm{b}}$ & - & 20.8 & - & 58.78 & - & - & 58.78 & [71] \\
\hline Scenedesmus sp. & F & - & 5.2 & 0.5 & $20^{\mathrm{b}}$ & - & - & - & - & - & - & - & [88] \\
\hline Scenedesmus sp. & I & 91 & 2 & $0.1-0.3$ & & - & - & $21-48.36$ & 36 & 24-55 & - & $40-80$ & [52] \\
\hline
\end{tabular}


The screening of native microalgae has been reported to be a suitable technique for integrated wastewater treatment and biomass accumulation [89]. Bohutskyi et al. [77] reported that the microalgae performing best in unsterilized wastewater were found to be clustered on the same branch of the phylogenetic tree. Combining microalgal screening and molecular phylogeny will be important in identifying the phenotypic traits and genes responsible for superior growth in wastewater. Following the fast development of omic technologies (e.g., genomics, transcriptomics, and proteomics), a large number of genomic, proteomic, and transcriptional data have become available for elucidating gene properties relevant to oil accumulation [90-92]. These will be valuable in the genetic engineering of microalgae for lipid production. Nevertheless there have been no reports of combining microalgal screening and omic technologies for microalgal growth and pollutant removal. Revealing the genetic traits of microalgal growth and nutrients removal via omic technologies and applying genetic engineering to improve productivity and nutrients removal abilities will be the focus of future research.

Even though the appropriately screened microalgae have shown excellent growth performance, their scaled cultivation with real secondary effluents in open systems is subject to strong competition (from local microalgal and microbial communities, when single microalgal bioprocesses are considered) and predation [93]. Single microalgal cultivation is also particularly sensitive to sudden changes in environmental conditions (such as light, temperature and nutrient availability) [93]. As reviewed by Fouilland [93], microalgal communities with high species richness and specific metabolic capacities were not only able to capture a high proportion of available resources for growth but also had their resilience enhanced. Microalgal-bacterial co-cultures also helped to ensure successful, intensive, stable microalgal production [93]. At present, preliminary attempts to establish a consortium for biomass production and pollutant removal in secondary effluent are being carried out, as seen in Section 2.4. Both microalgal poly-cultures and microalgal-bacterial co-cultures exhibited better performance than microalgal mono-cultures. However this research was in the early stages of tertiary wastewater treatment; importantly the consortium only contained two microalgae or an artificial combination of microalgae and bacteria. Constructing the consortium by natural selection, or by using an artificial assemblage of robust microalgal poly-cultures and microalgal-bacterial co-cultures with higher species richness and specific metabolic capacities, is of important practical value for tertiary wastewater treatment and lipid production.

\subsection{Carbon Supplementation by $\mathrm{CO}_{2}$ Sequestration in Secondary Effluent}

For microalgal cultivation, aeration provided by $\mathrm{CO}_{2}$ is not only beneficial to carbon accumulation via photosynthesis, but also contributes to mixing the culture, preventing settlement, and maintaining homogeneous conditions. Currently supplying pure $\mathrm{CO}_{2}$ or flue gas for microalgal cultivation prevails, and biomass and lipid content have thereby been increased in many microalgae [94]. Considering the serious lack of a carbon sources in secondary effluent, it has been necessary to investigate the relationship between $\mathrm{CO}_{2}$ supplements and biomass and lipid accumulation. Compared to microalgal cultivation without $\mathrm{CO}_{2}$ supplement, the biomass production and lipid content were enhanced in most cases when the concentration of pure $\mathrm{CO}_{2}$ supplied in secondary effluent ranged from $1 \%$ to $5 \%$ (Table 1). Flue gas produced by human activities is huge and can be regarded as a rich source of $\mathrm{CO}_{2}$. Apart from $\mathrm{CO}_{2}$, flue gas contains $\mathrm{N}_{2}, \mathrm{NO}_{x}, \mathrm{SO}_{x}, \mathrm{C}_{\mathrm{x}} \mathrm{H}_{\mathrm{y}}, \mathrm{CO}$, particulate matter, halogen acids, and heavy metals, which are toxic and likely to inhibit the microalgal growth if added to secondary effluent [95]. $\mathrm{CO}_{2}$ concentrations in flue gas were also found to be up to $6 \%-15 \%$, which can inhibit the growth of some microalgae [96]. This phenomenon was also found when microalgae were cultivated in secondary effluent with $15 \% \mathrm{CO}_{2}$ (Table 1). It is, therefore, critical to optimize the use of $\mathrm{CO}_{2}$ from flue gas for biomass production and lipid accumulation of microalgae in secondary effluent.

\subsection{Improving the Use of Nitrogen in Secondary Effluent}

Ammonium has been the preferred form of nitrogen because a redox reaction is not involved in its assimilation by microalgae [18]. Nitrate is used by microalgae only when the ammonium is low 
or depleted in the wastewater [18]. For WWTPs, the difference in processes or operation parameters resulted in differences in the abundance and richness of nitrifying and denitrifying bacteria $[97,98]$. These led to different nitrifying and denitrifying activities and then influenced the concentration of ammonium and nitrate in secondary effluent. Seasonal variation was also found likely to influence nitrifying and denitrifying activity via the temperature fluctuation [99]. Thus, to some extent, the ratio of ammonium/nitrate in secondary effluent was not constant and showed dynamic changes (Table 3). Enhancing the efficiency with which different forms of nitrogen (especially nitrate) are removed, in the light of possible nitrogen fluctuations in secondary effluent, will be a major concern.

Table 3. Characteristics of secondary effluent from different sources.

\begin{tabular}{|c|c|c|c|c|c|c|c|c|c|}
\hline $\begin{array}{l}\text { The Number of } \\
\text { Secondary } \\
\text { Effluent }\end{array}$ & $\begin{array}{l}\text { COD } \\
(\mathrm{mg} / \mathrm{L})\end{array}$ & $\begin{array}{c}\text { TOC } \\
(\mathrm{mg} / \mathrm{L})\end{array}$ & $\begin{array}{l}\text { BOD } \\
(\mathrm{mg} / \mathrm{L})\end{array}$ & $\begin{array}{c}\mathrm{TN} \\
(\mathrm{mg} / \mathrm{L})\end{array}$ & $\begin{array}{c}\mathrm{NH}_{4}{ }^{+}-\mathrm{N} \\
(\mathrm{mg} / \mathrm{L})\end{array}$ & $\begin{array}{l}\mathrm{NO}_{3}{ }^{-}-\mathrm{N} \\
(\mathrm{mg} / \mathrm{L})\end{array}$ & $\begin{array}{c}\mathrm{TP} \\
(\mathrm{mg} / \mathrm{L})\end{array}$ & $\mathrm{NO}_{3}{ }^{-}-\mathrm{N} / \mathrm{NH}_{4}{ }^{+}-\mathrm{N}$ & References \\
\hline 1 & - & 7.4 & - & 6.3 & $<0.01$ & 4.48 & 0.39 & $>448$ & [34] \\
\hline 2 & - & 5.5 & - & 8.9 & 0.17 & 7.67 & 0.04 & 45.11 & [34] \\
\hline 3 & $45-60$ & - & - & $12.5-23.8$ & $3.8-7.6$ & - & $0.82-1.67$ & - & [52] \\
\hline 4 & 24 & - & - & 15.5 & 2.5 & - & 0.5 & - & [33] \\
\hline 5 & - & - & - & - & 0.24 & 4.94 & $<0.01$ & 20.58 & {$[82]$} \\
\hline 6 & 56 & - & - & 22.13 & 4.10 & 15.12 & - & 3.69 & [100] \\
\hline 7 & - & - & - & 20.0 & 7.6 & 10.3 & 1.95 & 1.36 & [101] \\
\hline 8 & 24 & - & - & 7.0 & 0.50 & - & 0.46 & - & [35] \\
\hline 9 & 22.1 & - & - & 15.5 & 2.5 & - & 0.05 & - & [35] \\
\hline 10 & 24.5 & - & - & 16.7 & 3.7 & - & 0.08 & - & [35] \\
\hline 11 & 49.7 & - & - & 11.9 & 15.0 & 0.9 & 11.5 & 0.06 & [75] \\
\hline 12 & - & - & 10-19 & - & $21.62-28.85$ & - & $2.22-3.51$ & - & [70] \\
\hline 13 & - & 8.1 & - & 8.7 & 9.4 & 8.5 & 1.71 & 0.90 & [80] \\
\hline 14 & 100 & - & - & - & 21 & 1.6 & 5.6 & 0.08 & [38] \\
\hline
\end{tabular}

TOC: Total organic carbon; BOD: Biochemical oxygen demand.

\subsection{Growth of Microalgae in Unsterilized Secondary Effluent}

It has been difficult to sterilize or filter large amounts of secondary effluent to eliminate the potential effects of native organisms on microalgae in large-scale microalgal cultivation. Secondary effluent commonly contains some microorganisms, viruses, and predatory zooplankton, although their diversity and abundance are lower than in untreated wastewater. Microalgal growth is, therefore, likely to be affected when microalgae are cultivated in unsterilized secondary effluent. Lee et al. [102] found that Chlorogonium sp. outgrew other species in non-sterile secondary effluent. Zhang et al. [103] showed that Scenedesmus sp. ZTY1 exhibited good adaptability to secondary effluent. Although the growth rates of Chlorella sp. under conditions of non-sterilization were lower than under sterilization, non-sterile circumstances were beneficial for accumulating lipids and removing nutrients from secondary effluent [104]. In contrast, Bohutskyi et al. [77] found that most of the miroalgal species they tested were unable to grow efficiently in unsterilized secondary wastewater effluents. Yu et al. [105] showed that the growth of $C$. ellipsoidea was inhibited in unsterilized, domestic, secondary effluent. The potential mechanism was that soluble algal products accumulated in microalgal culture were used as a carbon source by bacteria and promoted bacterial growth. The overgrowth of bacteria then significantly inhibited the activity of microalgae. Based on the above results, there are some challenges for microalgal cultivation in unsterilized secondary effluent.

There has been considerable effort to promote the growth and lipid accumulation of microalgae in unsterilized secondary effluent. Supplementation with centrate from an anaerobic digester was found to be helpful in promoting biomass production in secondary effluent [106,107]. Appropriate doses of microalgal inoculum and correct light intensity also increased final biomass density and productivity in secondary wastewater [108]. The isolation of specific microalgae with excellent resistance to biotic pollution will be an important future goal. A successful example of screening microalgae with good biomass and lipid production in unsterilized wastewater has been reported [109]. Apart from improving the lipid content of microalgae via genetic engineering [110], it may be possible to enhance microalgal resistance to biotic pollution by genetic manipulation. Ultraviolet pretreatment of wastewater was found to increase microalgal growth rate and significantly reduce native bacterial 
densities [111]. However there has been almost no use of the above control technologies to enhance the growth of microalgae in unsterilized secondary effluent. Considerable work remains to be done.

\subsection{Development of Microalgal Harvesting Technologies}

Harvesting of the microalgal biomass has been a major bottleneck for biodiesel production, largely because of the small size of some cells (typically in the range of 3-30 $\mu \mathrm{m}$ ); the relatively low cell density, especially in the raceways $\left(<0.5 \mathrm{~kg} / \mathrm{m}^{3}\right.$ of dry biomass); and the large volume of water being harvested [112]. The recovery of microalgae generally requires one or more solid-liquid separation steps. Currently microalgal harvesting technologies include chemical flocculation, centrifugation, gravity sedimentation, filtration and screening, flotation, electrophoresis, and immobilization [113,114]. The immobilization technique, in particular, has been used effectively to separate microalgal cells from secondary effluent. However the huge consumption of chemicals and energy were major challenges. These drawbacks limited the use of these technologies for large-scale microalgal harvesting as they accounted for $20 \%-40 \%$ of the total costs of lipid production [112]. Some chemicals also showed a certain degree of biomass toxicity [115], and the high density of the immobilization matrix was likely to reduce the light penetrating through the reactor, thus affecting metabolic activity [62]. Theoretically self-settlement induced by exogenous selection pressures was beneficial to biomass-water separation. A typical case was the development of aerobic granular sludge by regulating some parameters such as settling time and the mixed liquor volume exchange ratio [116,117]. Valigore et al. [118] regulated hydraulic retention times and solids retention times of laboratory sequencing batch reactors to cultivate settleable microbial (microalgal-bacterial) biomass grown on primary treated wastewater as a biodiesel feedstock. They showed that biomass settleability was typically $70 \%-95 \%$, and the microbes, aggregated into compact flocs as cultures, aged up to 4 months. Related investigations, however, were only just beginning. In the future, it will be interesting to consider strengthening microalgal-water separation in secondary effluent, screening microalgae of high settleability via exogenous selection pressures.

\subsection{Use of Lipid-Extracted Algal Residues}

A scaled biodiesel production process will generate enormous amounts of lipid-extracted algal residues (LEA), containing major parts of the energy and all nutrients captured by microalgae. Rational use of LEA will help to reduce costs and develop a sustainable microalgal cultivation and biodiesel production process. Anaerobic digestion (AD) is a good choice, as this can convert LEA into a biogas, mainly consisting of $\mathrm{CH}_{4}$ and $\mathrm{CO}_{2}$, with traces of other gases such as $\mathrm{H}_{2} \mathrm{~S}$ [119]. Passing the biogas into the microalgae culture will not only benefit microalgal growth and nutrient removal, but also the purification of the biogas $[120,121]$. The biogas may be burned to produce electricity and to generate an onsite source for $\mathrm{CO}_{2}$ to supplement microalgae [122,123]. AD effluent, which contains many nutrients, can also be partially used as a chemical fertilizer during microalgal growth [106,107]. As elucidated by Bohutskyi et al. [107], the methane production from LEA increased the energy yield from microalgal biomass by more than $30 \%$. Additionally the supplementation of AD effluent during microalgae culture can reduce fertilizer costs by $45 \%$. Coupling biodiesel production and LEA use provides significant energy advantages as well as sustainability and economic benefits from nutrient recycling. However some factors will have a significant impact on the methane yield and productivity, notably (1) the difficulty in biodegrading microalgal cell walls; (2) the high protein content of the microalgal biomass, which results in high ammonium release; and (3) the high sodium concentration in microalgal cells, which may alter the anaerobic process. It will, therefore, be important to optimize LEA anaerobic digestion to ensure the absence of solvent residues inhibiting methanogens and to enhance LEA biodegradability for maximum methane yield, since some LEA fraction may be recalcitrant, as reviewed by some literatures [24,119]. 


\section{Conclusions}

Sustainability is a key principle in microalgal-based wastewater treatment and biodiesel production. It is important to consider how to minimize the environmental impact and strengthen the economic and social benefits of the process. This review underlines the viability of using secondary effluent as a potential medium for simultaneous microalgal growth and pollutant removal. As elucidated in the review, pollutant from secondary effluent can be effectively removed, and the lipid, as a renewable energy resource, is also accumulated by microalgae via fixing $\mathrm{CO}_{2}$. Immobilization of microalgae has significant advantages in promoting pollutants removal and also provides a beneficial physical barrier against native microorganisms in secondary effluent. A consortium of microalgae and/or bacteria results in greater biomass and lipid productivity and more effective removal of pollutants than is found in a mono-culture. Obviously it is feasible to integrate microalgal cultivation, as biodiesel production feedstock, with tertiary wastewater treatment. It is beneficial to reduce the risk of the eutrophication and carbon emissions. In addition, compared to oil crops for biodiesel production, it doesn't involve the conversion of agricultural land for biodiesel production or affect food security. Therefore it exhibits huge environmental and social benefits. However the high economic cost and the low efficiency (mainly in microalgal growth, lipid accumulation, and pollutant removal) have become the bottleneck of microalgal cultivation in secondary effluent. As potential solutions to these problems, considerable effort will be needed in the future to screen microalgae, construct the consortium, improve the use of flue gas and nitrogen, develop technologies for harvesting microalgae, and use LEA. Coupling biodiesel production and LEA use especially provides significant energy advantages, along with sustainability and economic benefits from nutrient recycling. In general, all these investigations represent potential approaches to integrating tertiary wastewater treatment and microalgal lipid accumulation for biodiesel production.

Acknowledgments: This research project was financed by the Key Scientific Development Project of Shanxi Province, China (No. FT-2014-01-15), the Natural Science Foundation of Shanxi Province, China (No. 2015021159), and the Social Development Foundation of Shanxi, China (No. 201603D321008).

Author Contributions: Junping Lv and Shulian Xie conducted literature review and summary. Junping Lv contributed to manuscript writing. Jia Feng and Qi Liu modified and processed original draft before submission of the manuscript.

Conflicts of Interest: The authors declare no conflict of interest.

\section{Abbreviations}

$\begin{array}{ll}\text { A } / O & \text { Anaerobic-anoxic-oxic } \\ \text { AD } & \text { Anaerobic digestion } \\ \text { ATS } & \text { Algal turf scrubber } \\ \text { BDOC } & \text { Biodegradable dissolved organic carbon } \\ \text { BNR } & \text { Biological nutrient removal } \\ \text { BOD } & \text { Biochemical oxygen demand } \\ \text { COD } & \text { Chemical oxygen demand } \\ \text { DOC } & \text { Dissolved organic carbon } \\ \text { HRAP } & \text { High rate alga pond } \\ \text { LEA } & \text { Lipid-extracted algal residues } \\ \text { RABR } & \text { Rotating algal biofilm reactor } \\ \text { SS } & \text { Suspension solid } \\ \text { TN } & \text { Total nitrogen } \\ \text { TOC } & \text { Total organic carbon } \\ \text { TP } & \text { Total phosphorous } \\ \text { TPBR } & \text { Tubular photobioreactor } \\ \text { UCT } & \text { University of Cape Town } \\ \text { WWTPs } & \text { Wastewater treatment plants }\end{array}$

\section{References}

1. Jin, L.; Zhang, G.; Tian, H. Current state of sewage treatment in China. Water Res. 2014, 66, 85-98. [CrossRef] [PubMed] 
2. Wagner, M.; Loy, A. Bacterial community composition and function in sewage treatment systems. Curr. Opin. Biotechnol. 2002, 13, 218-227. [CrossRef]

3. Wagner, M.; Rath, G.; Amann, R.; Koops, H.P.; Schleifer, K.H. In situ identification of ammonia-oxidizing bacteria. Syst. Appl. Microbiol. 1995, 18, 251-264. [CrossRef]

4. Chambers, P.A.; McGoldrick, D.J.; Brua, R.B.; Vis, C.; Culp, J.M.; Benoy, G.A. Development of environmental thresholds for nitrogen and phosphorus in streams. J. Environ. Qual. 2012, 41, 7-20. [CrossRef] [PubMed]

5. Acero, J.L.; Benitez, F.J.; Real, F.J.; Teva, F. Micropollutants removal from retentates generated in ultrafiltration and nanofiltration treatments of municipal secondary effluents by means of coagulation, oxidation, and adsorption processes. Chem. Eng. J. 2016, 289, 48-58. [CrossRef]

6. Daigger, G.T.; Waltrip, G.D.; Romm, E.D.; Morales, L.M. Enhanced secondary treatment incorporating biological nutrient removal. J. Water Pollut. Control Fed. 1988, 60, 1833-1842.

7. Kalkan, C.; Yapsakli, K.; Mertoglu, B.; Tufan, D.; Saatci, A. Evaluation of biological activated carbon (BAC) process in wastewater treatment secondary effluent for reclamation purposes. Desalination 2011, 265, 266-273. [CrossRef]

8. Sun, J.; Li, X.; Quan, Y.; Yin, Y.; Zheng, S. Effect of long-term organic removal on ion exchange properties and performance during sewage tertiary treatment by conventional anion exchange resins. Chemosphere 2015, 136, 181-189. [CrossRef] [PubMed]

9. Zhang, J.; Yu, H.; Quan, X.; Chen, S.; Zhang, Y. Ceramic membrane separation coupled with catalytic ozonation for tertiary treatment of dyestuff wastewater in a pilot-scale study. Chem. Eng. J. 2016, 301, 19-26. [CrossRef]

10. Zheng, S.K.; Chen, J.J.; Jiang, X.M.; Li, X.F. A comprehensive assessment on commercially available standard anion resins for tertiary treatment of municipal wastewater. Chem. Eng. J. 2011, 169, 194-199. [CrossRef]

11. Arita, C.E.Q.; Peebles, C.; Bradley, T.H. Scalability of combining microalgae-based biofuels with wastewater facilities: A review. Algal Res. 2015, 9, 160-169. [CrossRef]

12. Höök, M.; Tang, X. Depletion of fossil fuels and anthropogenic climate change-A review. Energy Policy 2013, 52, 797-809. [CrossRef]

13. Kampa, M.; Castanas, E. Human health effects of air pollution. Environ. Pollut. 2008, 151, 362-367. [CrossRef] [PubMed]

14. Adewale, P.; Dumont, M.J.; Ngadi, M. Recent trends of biodiesel production from animal fat wastes and associated production techniques. Rene. Sustain Energy. Rev. 2015, 45, 574-588. [CrossRef]

15. Beringer, T.I.M.; Lucht, W.; Schaphoff, S. Bioenergy production potential of global biomass plantations under environmental and agricultural constraints. GCB Bioenergy 2011, 3, 299-312. [CrossRef]

16. Petrou, E.C.; Pappis, C.P. Biofuels: A survey on pros and cons. Energy Fuel 2009, 23, 1055-1066. [CrossRef]

17. Ahmad, A.L.; Yasin, N.H.; Derek, C.J.C.; Lim, J.K. Microalgae as a sustainable energy source for biodiesel production: A review. Renew. Sustain Energy Rev. 2011, 15, 584-593. [CrossRef]

18. Cai, T.; Park, S.Y.; Li, Y. Nutrient recovery from wastewater streams by microalgae: Status and prospects. Renew. Sustain Energy. Rev. 2013, 19, 360-369. [CrossRef]

19. Hosseini, M.; Ju, L.K. Use of phagotrophic microalga Ochromonas danica to pretreat waste cooking oil for biodiesel production. J. Am. Oil Chem. Soc. 2015, 92, 29-35. [CrossRef]

20. Nascimento, I.A.; Marques, S.S.I.; Cabanelas, I.T.D.; de Carvalho, G.C.; Nascimento, M.A.; de Souza, C.O.; Druzian, J.I.; Hussain, J.; Liao, W. Microalgae versus land crops as feedstock for biodiesel: Productivity, quality, and standard compliance. Bioenergy Res. 2014, 7, 1002-1013. [CrossRef]

21. Demirbas, A.; Demirbas, M.F. Importance of algae oil as a source of biodiesel. Energy Convers. Manag. 2011, 52, 163-170. [CrossRef]

22. Bohutskyi, P.; Bouwer, E. Biogas production from algae and cyanobacteria through anaerobic digestion: A review, analysis, and research needs. In Advanced Biofuels and Bioproducts; Lee, J.W., Ed.; Springer: New York, NY, USA, 2012; pp. 873-975.

23. Harun, R.; Davidson, M.; Doyle, M.; Gopiraj, R.; Danquah, M.; Forde, G. Technoeconomic analysis of an integrated microalgae photobioreactor, biodiesel and biogas production facility. Biomass Bioenergy 2011, 35, 741-747. [CrossRef] 
24. Sialve, B.; Bernet, N.; Bernard, O. Anaerobic digestion of microalgae as a necessary step to make microalgal biodiesel sustainable. Biotechnol. Adv. 2009, 27, 409-416. [CrossRef] [PubMed]

25. Jeon, H.; Lee, Y.; Chang, K.S.; Lee, C.G.; Jin, E. Enhanced production of biomass and lipids by supplying $\mathrm{CO}_{2}$ in marine microalga Dunaliella sp. J. Microbiol. 2013, 51, 773-776. [CrossRef] [PubMed]

26. Kao, C.Y.; Chen, T.Y.; Chang, Y.B.; Chiu, T.W.; Lin, H.Y.; Chen, C.D.; Chang, J.H.; Lin, C.S. Utilization of carbon dioxide in industrial flue gases for the cultivation of microalga Chlorella sp. Bioresour. Technol. 2014, 166, 485-493. [CrossRef] [PubMed]

27. Chen, G.; Zhao, L.; Qi, Y. Enhancing the productivity of microalgae cultivated in wastewater toward biofuel production: A critical review. Appl. Energy 2015, 137, 282-291. [CrossRef]

28. Zeng, X.; Guo, X.; Su, G.; Danquah, M.K.; Zhang, S.; Lu, Y.; Sun, Y.; Lin, L. Bioprocess considerations for microalgal-based wastewater treatment and biomass production. Renew. Sustain Energy. Rev. 2015, 42, 1385-1392. [CrossRef]

29. Li, X.; Hu, H.Y.; Gan, K.; Sun, Y.X. Effects of different nitrogen and phosphorus concentrations on the growth, nutrient uptake, and lipid accumulation of a freshwater microalga Scenedesmus sp. Bioresour. Technol. 2010, 101, 5494-5500.

30. Min, M.; Wang, L.; Li, Y.; Mohr, M.J.; Hu, B.; Zhou, W.; Chen, P.; Ruan, R. Cultivating Chlorella sp. in a pilot-scale photobioreactor using centrate wastewater for microalgae biomass production and wastewater nutrient removal. Appl. Biochem. Biotechnol. 2011, 165, 123-137. [CrossRef] [PubMed]

31. Zhang, Y.; Su, H.; Zhong, Y.; Zhang, C.; Shen, Z.; Sang, W.; Yan, G.; Zhou, X. The effect of bacterial contamination on the heterotrophic cultivation of Chlorella pyrenoidosa in wastewater from the production of soybean products. Water Res. 2012, 46, 5509-5516. [CrossRef] [PubMed]

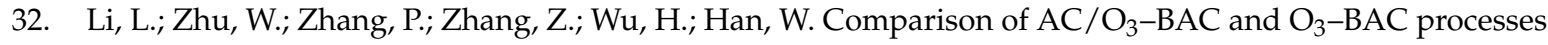
for removing organic pollutants in secondary effluent. Chemosphere 2006, 62, 1514-1522. [CrossRef] [PubMed]

33. Li, X.; Hu, H.Y.; Yang, J. Lipid accumulation and nutrient removal properties of a newly isolated freshwater microalga, Scenedesmus sp. LX1, growing in secondary effluent. New Biotechnol. 2010, 27, 59-63.

34. Sawayama, S.; Minowa, T.; Dote, Y.; Yokoyama, S. Growth of the hydrocarbon-rich microalga Botryococcus braunii in secondarily treated sewage. Appl. Microbiol. Biotechnol. 1992, 38, 135-138. [CrossRef]

35. Yang, J.; Li, X.; Hu, H.Y.; Zhang, X.; Yu, Y.; Chen, Y. Growth and lipid accumulation properties of a freshwater microalga, Chlorella ellipsoidea YJ1, in domestic secondary effluents. Appl. Energy 2011, 88, 3295-3299. [CrossRef]

36. Chevalier, P.; Proulx, D.; Lessard, P.; Vincent, W.F.; de la Noüe, J. Nitrogen and phosphorus removal by high latitude mat-forming cyanobacteria for potential use in tertiary wastewater treatment. J. Appl. Phycol. 2000, 12, 105-112. [CrossRef]

37. Tang, E.P.; Vincent, W.F.; Proulx, D.; Lessard, P.; de la Noüe, J. Polar cyanobacteria versus green algae for tertiary waste-water treatment in cool climates. J. Appl. Phycol. 1997, 9, 371-381. [CrossRef]

38. Arbib, Z.; Ruiz, J.; Álvarez-Díaz, P.; Garrido-Pérez, C.; Perales, J.A. Capability of different microalgae species for phytoremediation processes: Wastewater tertiary treatment, $\mathrm{CO}_{2}$ bio-fixation and low cost biofuels production. Water Res. 2014, 49, 465-474. [CrossRef] [PubMed]

39. Sydney, E.B.; Da Silva, T.E.; Tokarski, A.; Novak, A.C.; de Carvalho, J.C.; Woiciecohwski, A.L.; Larroche, C.; Soccol, C.R. Screening of microalgae with potential for biodiesel production and nutrient removal from treated domestic sewage. Appl. Energy 2011, 88, 3291-3294. [CrossRef]

40. Park, K.C.; Whitney, C.; McNichol, J.C.; Dickinson, K.E.; MacQuarrie, S.; Skrupski, B.P.; Zou, J.T.; Wilson, K.E.; O'Leary, S.J.B.; McGinn, P.J. Mixotrophic and photoautotrophic cultivation of 14 microalgae isolates from Saskatchewan, Canada: Potential applications for wastewater remediation for biofuel production. J. Appl. Phycol. 2012, 24, 339-348. [CrossRef]

41. Gómez-Serrano, C.; Morales-Amaral, M.M.; Acién, F.G.; Escudero, R.; Fernández-Sevilla, J.M.; Molina-Grima, E. Utilization of secondary-treated wastewater for the production of freshwater microalgae. Appl. Microbiol. Biotechnol. 2015, 99, 6931-6944. [CrossRef] [PubMed]

42. Kaya, V.M.; de la Noüe, J.; Picard, G. A comparative study of four systems for tertiary wastewater treatment by Scenedesmus bicellularis: New technology for immobilization. J. Appl. Phycol. 1995, 7, 85-95. [CrossRef]

43. Zhang, E.; Wang, B.; Wang, Q.; Zhang, S.; Zhao, B. Ammonia-nitrogen and orthophosphate removal by immobilized Scenedesmus sp. isolated from municipal wastewater for potential use in tertiary treatment. Bioresour. Technol. 2008, 99, 3787-3793. [CrossRef] [PubMed] 
44. Zhang, E.; Wang, B.; Ning, S.; Sun, H.; Yang, B.; Jin, M.; Hou, L. Ammonia-nitrogen and orthophosphate removal by immobilized Chlorella sp. isolated from municipal wastewater for potential use in tertiary treatment. Afr. J. Biotechnol. 2012, 11, 6529-6534.

45. Chevalier, P.; de la Noüe, J. Efficiency of immobilized hyperconcentrated algae for ammonium and orthophosphate removal from wastewaters. Biotechnol. Lett. 1985, 7, 395-400. [CrossRef]

46. De la Noüe, J.; Proulx, D. Biological tertiary treatment of urban wastewaters with chitosan-immobilized Phormidium. Appl. Microbiol. Biotechnol. 1988, 29, 292-297. [CrossRef]

47. Kaya, V.M.; Picard, G. Stability of chitosan gel as entrapment matrix of viable Scenedesmus bicellularis cells immobilized on screens for tertiary treatment of wastewater. Bioresour. Technol. 1996, 56, 147-155. [CrossRef]

48. Tam, N.F.Y.; Wong, Y.S. Effect of immobilized microalgal bead concentrations on wastewater nutrient removal. Environ. Pollut. 2000, 107, 145-151. [CrossRef]

49. Covarrubias, S.A.; de-Bashan, L.E.; Moreno, M.; Bashan, Y. Alginate beads provide a beneficial physical barrier against native microorganisms in wastewater treated with immobilized bacteria and microalgae. Appl. Microbiol. Biotechnol. 2012, 93, 2669-2680. [CrossRef] [PubMed]

50. Palmer, J.; Flint, S.; Brooks, J. Bacterial cell attachment, the beginning of a biofilm. J. Ind. Microbiol. Biotechnol. 2007, 34, 577-588. [CrossRef] [PubMed]

51. Gao, F.; Yang, Z.H.; Li, C.; Zeng, G.M.; Ma, D.H.; Zhou, L. A novel algal biofilm membrane photobioreactor for attached microalgae growth and nutrients removal from secondary effluent. Bioresour. Technol. 2015, 179, 8-12. [CrossRef] [PubMed]

52. He, S.; Xue, G. Algal-based immobilization process to treat the effluent from a secondary wastewater treatment plant (WWTP). J. Hazard. Mater. 2010, 178, 895-899. [CrossRef] [PubMed]

53. Sukačová, K.; Trtílek, M.; Rataj, T. Phosphorus removal using a microalgal biofilm in a new biofilm photobioreactor for tertiary wastewater treatment. Water Res. 2015, 71, 55-63. [CrossRef] [PubMed]

54. Christenson, L.B.; Sims, R.C. Rotating algal biofilm reactor and spool harvester for wastewater treatment with biofuels by-products. Biotechnol. Bioeng. 2012, 109, 1674-1684. [CrossRef] [PubMed]

55. Gross, M.; Henry, W.; Michael, C.; Wen, Z. Development of a rotating algal biofilm growth system for attached microalgae growth with in situ biomass harvest. Bioresour. Technol. 2013, 150, 195-201. [CrossRef] [PubMed]

56. Adey, W.H.; Kangas, P.C.; Mulbry, W. Algal turf scrubbing: Cleaning surface waters with solar energy while producing a biofuel. Bioscience 2011, 61, 434-441. [CrossRef]

57. Bohutskyi, P.; Chow, S.; Ketter, B.; Shek, C.F.; Yacar, D.; Tang, Y.; Bouwer, E.J. Phytoremediation of agriculture runoff by filamentous algae poly-culture for biomethane production, and nutrient recovery for secondary cultivation of lipid generating microalgae. Bioresour. Technol. 2016, 222, 294-308. [CrossRef] [PubMed]

58. Craggs, R.J.; Adey, W.H.; Jenson, K.R.; John, M.S.S.; Green, F.B.; Oswald, W.J. Phosphorus removal from wastewater using an algal turf scrubber. Water Sci. Technol. 1996, 33, 191-198. [CrossRef]

59. Craggs, R.J.; Adey, W.H.; Jessup, B.K.; Oswald, W.J. A controlled stream mesocosm for tertiary treatment of sewage. Ecol. Eng. 1996, 6, 149-169. [CrossRef]

60. Cruz, I.; Bashan, Y.; Hernàndez-Carmona, G.; de-Bashan, L.E. Biological deterioration of alginate beads containing immobilized microalgae and bacteria during tertiary wastewater treatment. Appl. Microbiol. Biotechnol. 2013, 97, 9847-9858. [CrossRef] [PubMed]

61. Hoffmann, J.P. Wastewater treatment with suspended and nonsuspended algae. J. Phycol. 1998, 34, 757-763. [CrossRef]

62. Ruiz-Marin, A.; Mendoza-Espinosa, L.G.; Stephenson, T. Growth and nutrient removal in free and immobilized green algae in batch and semi-continuous cultures treating real wastewater. Bioresour. Technol. 2010, 101, 58-64. [CrossRef] [PubMed]

63. Mahdavi, H.; Prasad, V.; Liu, Y.; Ulrich, A.C. In situ biodegradation of naphthenic acids in oil sands tailings pond water using indigenous algae-bacteria consortium. Bioresour. Technol. 2015, 187, 97-105. [CrossRef] [PubMed]

64. Maza-Márquez, P.; Martinez-Toledo, M.V.; Fenice, M.; Andrade, L.; Lasserrot, A.; Gonzalez-Lopez, J. Biotreatment of olive washing wastewater by a selected microalgal-bacterial consortium. Int. Biodeterior. Biodegrad. 2014, 88, 69-76. [CrossRef] 
65. Zhao, X.; Zhou, Y.; Huang, S.; Qiu, D.; Schideman, L.; Chai, X.; Zhao, Y. Characterization of microalgae-bacteria consortium cultured in landfill leachate for carbon fixation and lipid production. Bioresour. Technol. 2014, 156, 322-328. [CrossRef] [PubMed]

66. Subashchandrabose, S.R.; Ramakrishnan, B.; Megharaj, M.; Venkateswarlu, K.; Naidu, R. Consortia of cyanobacteria/microalgae and bacteria: Biotechnological potential. Biotechnol. Adv. 2011, 29, 896-907. [CrossRef] [PubMed]

67. De-Bashan, L.E.; Hernandez, J.P.; Morey, T.; Bashan, Y. Microalgae growth-promoting bacteria as "helpers" for microalgae: A novel approach for removing ammonium and phosphorus from municipal wastewater. Water Res. 2004, 38, 466-474. [CrossRef] [PubMed]

68. Zhu, S.F.; Yu, Y.; Hu, H.Y. Effects on the growth characteristic by mixed culture of three energy microalgae species using domestic secondary effluent. Ecol. Environ. Sci. 2014, 23, 642-648. (In Chinese)

69. Van Coillie, R.; del la Noue, J.; Thellen, C.; Pouliot, Y. Tertiary domestic waste water treatment by Scenedesmus sp. pilot-scale culture. Revue des Sciences de l'Eau 1990, 3, 441-455. (In French) [CrossRef]

70. McGinn, P.J.; Dickinson, K.E.; Park, K.C.; Whitney, C.G.; MacQuarrie, S.P.; Black, F.J.; Frigon, J.C.; Guiot, S.R.; O'Leary, S.J.B. Assessment of the bioenergy and bioremediation potentials of the microalga Scenedesmus sp. AMDD cultivated in municipal wastewater effluent in batch and continuous mode. Algal Res. 2012, 1, 155-165. [CrossRef]

71. Arbib, Z.; Ruiz, J.; Álvarez-Díaz, P.; Garrido-Pérez, C.; Barragan, J.; Perales, J.A. Long term outdoor operation of a tubular airlift pilot photobioreactor and a high rate algal pond as tertiary treatment of urban wastewater. Ecol. Eng. 2013, 52, 143-153. [CrossRef]

72. Wu, Y.H.; Hu, H.Y.; Yu, Y.; Zhang, T.Y.; Zhu, S.F.; Zhuang, L.L.; Zhang, X.; Lu, Y. Microalgal species for sustainable biomass/lipid production using wastewater as resource: A review. Renew. Sustain Energy Rev. 2014, 33, 675-688. [CrossRef]

73. Chiu, S.Y.; Kao, C.Y.; Chen, T.Y.; Chang, Y.B.; Kuo, C.M.; Lin, C.S. Cultivation of microalgal Chlorella for biomass and lipid production using wastewater as nutrient resource. Bioresour. Technol. 2015, 184, 179-189. [CrossRef] [PubMed]

74. Maity, J.P.; Bundschuh, J.; Chen, C.Y.; Bhattacharya, P. Microalgae for third generation biofuel production, mitigation of greenhouse gas emissions and wastewater treatment: Present and future perspectives-A mini review. Energy 2014, 78, 104-113. [CrossRef]

75. Órpez, R.; Martínez, M.E.; Hodaifa, G.; El Yousfi, F.; Jbari, N.; Sánchez, S. Growth of the microalga Botryococcus braunii in secondarily treated sewage. Desalination 2009, 246, 625-630. [CrossRef]

76. Lizzul, A.M.; Hellier, P.; Purton, S.; Baganz, F.; Ladommatos, N.; Campos, L. Combined remediation and lipid production using Chlorella sorokiniana grown on wastewater and exhaust gases. Bioresour. Technol. 2014, 151, 12-18. [CrossRef] [PubMed]

77. Bohutskyi, P.; Liu, K.; Nasr, L.K.; Byers, N.; Rosenberg, J.N.; Oyler, G.A.; Betenbaugh, M.J.; Bouwer, E.J. Bioprospecting of microalgae for integrated biomass production and phytoremediation of unsterilized wastewater and anaerobic digestion centrate. Appl. Microbiol. Biotechnol. 2015, 99, 6139-6154. [CrossRef] [PubMed]

78. Cho, S.; Luong, T.T.; Lee, D.; Oh, Y.K.; Lee, T. Reuse of effluent water from a municipal wastewater treatment plant in microalgae cultivation for biofuel production. Bioresour. Technol. 2011, 102, 8639-8645. [CrossRef] [PubMed]

79. Cabanelas, I.T.D.; Ruiz, J.; Arbib, Z.; Chinalia, F.A.; Garrido-Pérez, C.; Rogalla, F.; Nascimento, I.A.; Perale, J.A. Comparing the use of different domestic wastewaters for coupling microalgal production and nutrient removal. Bioresour. Technol. 2013, 131, 429-436. [CrossRef] [PubMed]

80. Ji, M.K.; Abou-Shanab, R.A.; Kim, S.H.; Salama, E.S.; Lee, S.H.; Kabra, A.N.; Lee, Y.S.; Hong, S.; Jeon, B.H. Cultivation of microalgae species in tertiary municipal wastewater supplemented with $\mathrm{CO}_{2}$ for nutrient removal and biomass production. Ecol. Eng. 2013, 58, 142-148. [CrossRef]

81. Ebrahimian, A.; Kariminia, H.R.; Vosoughi, M. Lipid production in mixotrophic cultivation of Chlorella vulgaris in a mixture of primary and secondary municipal wastewater. Renew. Energ. 2014, 71, 502-508. [CrossRef] 
82. Samorì, G.; Samorì, C.; Guerrini, F.; Pistocchi, R. Growth and nitrogen removal capacity of Desmodesmus communis and of a natural microalgae consortium in a batch culture system in view of urban wastewater treatment: Part I. Water Res. 2013, 47, 791-801. [CrossRef] [PubMed]

83. Wang, B.; Lan, C.Q. Biomass production and nitrogen and phosphorus removal by the green alga Neochloris oleoabundans in simulated wastewater and secondary municipal wastewater effluent. Bioresour. Technol. 2011, 102, 5639-5644. [CrossRef] [PubMed]

84. Martınez, M.E.; Sánchez, S.; Jimenez, J.M.; El Yousfi, F.; Munoz, L. Nitrogen and phosphorus removal from urban wastewater by the microalga Scenedesmus obliquus. Bioresour. Technol. 2000, 73, 263-272. [CrossRef]

85. Li, X.; Hu, H.Y.; Zhang, Y.P. Effect of inorganic carbon supplement on the growth and lipid accumulation properties of Scenedesmus sp. LX1. Environ. Sci. 2011, 32, 2260-2266. (In Chinese)

86. Kaya, V.M.; Goulet, J.; de la Noüe, J.; Picard, G. Effect of intermittent $\mathrm{CO}_{2}$ enrichment during nutrient starvation on tertiary treatment of wastewater by alginate-immobilized Scenedesmus bicellularis. Enzym. Microb. Technol. 1996, 18, 550-554. [CrossRef]

87. Xu, M.; Li, P.; Tang, T.; Hu, Z. Roles of SRT and HRT of an algal membrane bioreactor system with a tanks-in-series configuration for secondary wastewater effluent polishing. Ecol. Eng. 2015, 85, 257-264. [CrossRef]

88. Wu, Y.H.; Li, X.; Yu, Y.; Hu, H.Y.; Zhang, T.Y.; Li, F.M. An integrated microalgal growth model and its application to optimize the biomass production of Scenedesmus sp. LX1 in open pond under the nutrient level of domestic secondary effluent. Bioresour. Technol. 2013, 144, 445-451. [CrossRef] [PubMed]

89. Lynch, F.; Santana-Sánchez, A.; Jämsä, M.; Sivonen, K.; Aro, E.M.; Allahverdiyeva, Y. Screening native isolates of cyanobacteria and a green alga for integrated wastewater treatment, biomass accumulation and neutral lipid production. Algal Res. 2015, 11, 411-420. [CrossRef]

90. Choi, Y.E.; Hwang, H.; Kim, H.S.; Ahn, J.W.; Jeong, W.J.; Yang, J.W. Comparative proteomics using lipid over-producing or less-producing mutants unravels lipid metabolisms in Chlamydomonas reinhardtii. Bioresour. Technol. 2013, 145, 108-115. [CrossRef] [PubMed]

91. De Lomana, A.L.G.; Schäuble, S.; Valenzuela, J.; Imam, S.; Carter, W.; Bilgin, D.D.; Price, N.D. Transcriptional program for nitrogen starvation-induced lipid accumulation in Chlamydomonas reinhardtii. Biotechnol. Biofuels 2015, 8, 207. [CrossRef] [PubMed]

92. Gao, C.; Wang, Y.; Shen, Y.; Yan, D.; He, X.; Dai, J.; Wu, Q. Oil accumulation mechanisms of the oleaginous microalga Chlorella protothecoides revealed through its genome, transcriptomes, and proteomes. BMC Genom. 2014, 15, 582. [CrossRef] [PubMed]

93. Fouilland, E. Biodiversity as a tool for waste phycoremediation and biomass production. Rev. Environ. Sci. Biol. 2012, 11, 1-4. [CrossRef]

94. Cheah, W.Y.; Show, P.L.; Chang, J.S.; Ling, T.C.; Juan, J.C. Biosequestration of atmospheric $\mathrm{CO}_{2}$ and flue gas-containing $\mathrm{CO}_{2}$ by microalgae. Bioresour. Technol. 2015, 84, 190-201. [CrossRef] [PubMed]

95. Van Den Hende, S.; Vervaeren, H.; Boon, N. Flue gas compounds and microalgae: (Bio-)chemical interactions leading to biotechnological opportunities. Biotechnol. Adv. 2012, 30, 1405-1424. [CrossRef] [PubMed]

96. Zhao, B.; Su, Y. Process effect of microalgal-carbon dioxide fixation and biomass production: A review. Renew. Sustain Energy. Rev. 2014, 31, 121-132. [CrossRef]

97. Krasner, S.W.; Westerhoff, P.; Chen, B.; Rittmann, B.E.; Nam, S.N.; Amy, G. Impact of wastewater treatment processes on organic carbon, organic nitrogen, and DBP precursors in effluent organic matter. Environ. Sci. Technol. 2009, 43, 2911-2918. [CrossRef] [PubMed]

98. Pochana, K.; Keller, J. Study of factors affecting simultaneous nitrification and denitrification (SND). Water Sci. Technol. 1999, 39, 61-68. [CrossRef]

99. Zhang, B.; Yamamoto, K. Seasonal change of microbial population and activities in a building wastewater reuse system using a membrane separation activated sludge process. Water Sci. Technol. 1996, 34, $295-302$. [CrossRef]

100. Xiong, J.; Guo, G.; Mahmood, Q.; Yue, M. Nitrogen removal from secondary effluent by using integrated constructed wetland system. Ecol. Eng. 2011, 37, 659-662. [CrossRef]

101. Abe, K.; Komada, M.; Ookuma, A.; Itahashi, S.; Banzai, K. Purification performance of a shallow free-water-surface constructed wetland receiving secondary effluent for about 5 years. Ecol. Eng. 2014, 69, 126-133. [CrossRef] 
102. Lee, K.Y.; Ng, T.W.; Li, G.; An, T.; Kwan, K.K.; Chan, K.M.; Huang, G.; Yip, H.Y.; Wong, P.K. Simultaneous nutrient removal, optimised $\mathrm{CO}_{2}$ mitigation and biofuel feedstock production by Chlorogonium sp. grown in secondary treated non-sterile saline sewage effluent. J. Hazard. Mater. 2015, 297, 241-250. [CrossRef] [PubMed]

103. Zhang, T.Y.; Wu, Y.H.; Hu, H.Y. Domestic wastewater treatment and biofuel production by using microalga Scenedesmus sp. ZTY1. Water Sci. Technol. 2014, 69, 2492-2496. [CrossRef] [PubMed]

104. Zhang, Q.; Hong, Y. Comparison in growth, lipid accumulation, and nutrient removal capacities of Chlorella sp. in secondary effluents under sterile and non-sterile conditions. Water Sci. Technol. 2012, 69, 573-579. [CrossRef] [PubMed]

105. Yu, Y.; Wu, Y.H.; Zhu, S.F.; Hu, H.Y. The bioavailability of the soluble algal products of different microalgal strains and its influence on microalgal growth in unsterilized domestic secondary effluent. Bioresour. Technol. 2015, 180, 352-355. [CrossRef] [PubMed]

106. Bohutskyi, P.; Chow, S.; Ketter, B.; Betenbaugh, M.J.; Bouwer, E.J. Prospects for methane production and nutrient recycling from lipid extracted residues and whole Nannochloropsis salina using anaerobic digestion. Appl. Energ. 2015, 154, 718-731. [CrossRef]

107. Bohutskyi, P.; Ketter, B.; Chow, S.; Adams, K.J.; Betenbaugh, M.J.; Allnutt, F.T.; Bouwer, E.J. Anaerobic digestion of lipid-extracted Auxenochlorella protothecoides biomass for methane generation and nutrient recovery. Bioresour. Technol. 2015, 183, 229-239. [CrossRef] [PubMed]

108. Bohutskyi, P.; Kligerman, D.C.; Byers, N.; Nasr, L.K.; Cua, C.; Chow, S.; Su, C.; Tang, Y.; Betenbaugh, M.J.; Bouwer, E.J. Effects of inoculum size, light intensity, and dose of anaerobic digestion centrate on growth and productivity of Chlorella and Scenedesmus microalgae and their poly-culture in primary and secondary wastewater. Algal Res. 2016, 19, 278-290. [CrossRef]

109. Chinnasamy, S.; Bhatnagar, A.; Hunt, R.W.; Das, K.C. Microalgae cultivation in a wastewater dominated by carpet mill effluents for biofuel applications. Bioresour. Technol. 2010, 101, 3097-3105. [CrossRef] [PubMed]

110. Ho, S.H.; Ye, X.; Hasunuma, T.; Chang, J.S.; Kondo, A. Perspectives on engineering strategies for improving biofuel production from microalgae-A critical review. Biotechnol. Adv. 2014, 32, 1448-1459. [CrossRef] [PubMed]

111. Passero, M.L.; Cragin, B.; Hall, A.R.; Staley, N.; Coats, E.R.; McDonald, A.G.; Feris, K. Ultraviolet radiation pre-treatment modifies dairy wastewater, improving its utility as a medium for algal cultivation. Algal Res. 2014, 6, 98-110. [CrossRef]

112. Olguín, E.J. Dual purpose microalgae-bacteria-based systems that treat wastewater and produce biodiesel and chemical products within a biorefinery. Biotechnol. Adv. 2012, 30, 1031-1046. [CrossRef] [PubMed]

113. Amaro, H.M.; Guedes, A.; Malcata, F.X. Advances and perspectives in using microalgae to produce biodiesel. Appl. Energy 2011, 88, 3402-3410. [CrossRef]

114. Rawat, I.; Ranjith Kumar, R.; Mutanda, T.; Bux, F. Dual role of microalgae: Phycoremediation of domestic wastewater and biomass production for sustainable biofuels production. Appl. Energy 2011, 88, 3411-3424. [CrossRef]

115. Rawat, I.; Kumar, R.R.; Mutanda, T.; Bux, F. Biodiesel from microalgae: A critical evaluation from laboratory to large scale production. Appl. Energy 2013, 103, 444-467. [CrossRef]

116. Adav, S.S.; Lee, D.J.; Show, K.Y.; Tay, J.H. Aerobic granular sludge: Recent advances. Biotechnol. Adv. 2008, 26, 411-423. [CrossRef] [PubMed]

117. Wang, Z.W.; Liu, Y.; Tay, J.H. The role of SBR mixed liquor volume exchange ratio in aerobic granulation. Chemosphere 2006, 62, 767-771. [CrossRef] [PubMed]

118. Valigore, J.M.; Gostomski, P.A.; Wareham, D.G.; O'Sullivan, A.D. Effects of hydraulic and solids retention times on productivity and settleability of microbial (microalgal-bacterial) biomass grown on primary treated wastewater as a biofuel feedstock. Water Res. 2012, 46, 2957-2964. [CrossRef] [PubMed]

119. Tan, C.H.; Show, P.L.; Chang, J.S.; Ling, T.C.; Lan, J.C.W. Novel approaches of producing bioenergies from microalgae: A recent review. Biotechnol. Adv. 2015, 33, 1219-1227. [CrossRef] [PubMed]

120. Conde, J.L.; Moro, L.E.; Travieso, L.; Sanchez, E.P.; Leiva, A.; Dupeiron, R.; Escobedo, R. Biogas purification process using intensive microalgae cultures. Biotechnol. Lett. 1993, 15, 317-320. [CrossRef]

121. Heubeck, S.; Craggs, R.J.; Shilton, A. Influence of $\mathrm{CO}_{2}$ scrubbing from biogas on the treatment performance of a high rate algal pond. Water Sci. Technol. 2007, 55, 193-200. [CrossRef] [PubMed] 
122. Doušková, I.; Kaštánek, F.; Maléterová, Y.; Kaštánek, P.; Doucha, J.; Zachleder, V. Utilization of distillery stillage for energy generation and concurrent production of valuable microalgal biomass in the sequence: Biogas-cogeneration-microalgae-products. Energy Convers. Manag. 2010, 51, 606-611. [CrossRef]

123. Holm-Nielsen, J.B.; Al Seadi, T.; Oleskowicz-Popiel, P. The future of anaerobic digestion and biogas utilization. Bioresour. Technol. 2009, 100, 5478-5484. [CrossRef] [PubMed]

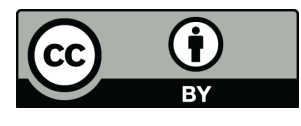

(c) 2017 by the authors; licensee MDPI, Basel, Switzerland. This article is an open access article distributed under the terms and conditions of the Creative Commons Attribution (CC-BY) license (http://creativecommons.org/licenses/by/4.0/). 